\title{
Tubular Effects of Insulin
}

\author{
Nobuyuki Takahashi, Osamu Ito, and Keishi Abe
}

\begin{abstract}
The direct effect of insulin on $\mathrm{NaCl}$ transport in proximal tubules and thick ascending limbs of Henle's loop were examined. First, the effects of insulin on intracellular pH (pHi) in the in vitro microperfused rabbit S2 proximal straight tubules (PST) were examined using a fluorescent technique. Addition of insulin to the bath increased pHi in a dose-dependent manner at concentrations ranging from $10^{-11}$ to $10^{-6} \mathrm{~mol} / \mathrm{l}$, and its $\mathrm{ED}_{50}$ was $10^{-9} \mathrm{~mol} / \mathrm{l}$. The insulin-induced $\mathrm{pHi}$ increase was almost completely inhibited by $10^{-3} \mathrm{~mol} / \mathrm{l}$ amiloride in the lumen, indicating that insulin activates luminal $\mathrm{Na} / \mathrm{H}$ exchange in PST. Next, the effect of insulin on the transepithelial voltage $(\mathrm{Vt})$ and lumen-to-bath $\mathrm{Cl}$ flux $\left(\mathrm{J}_{\mathrm{Cl}}\right)$ were examined in the in vitro microperfused rabbit medullary thick ascending limbs of Henle's loop (MTAL). Insulin in the bath increased Vt in a dose-dependent manner, and its $\mathrm{ED}_{50}$ was $5 \times 10^{-9} \mathrm{~mol} / \mathrm{l}$. Insulin significantly increased $\mathrm{J}_{\mathrm{Cl}}$. The insulin-mediated increase in $\mathrm{Vt}$ was abolished by ouabain and furosemide. Dibutyryl-cAMP (dbcAMP) increased $\mathrm{Vt}$ and $\mathrm{J}_{\mathrm{Cl}}$. $\mathrm{H}-\mathrm{8}$ abolished the effect of dbcAMP, while it did not inhibit the actions of insulin. Removal of extracellular Ca did not affect the effects of insulin on $\mathrm{Vt}$ and $\mathrm{J}_{\mathrm{Cl}}$. Chelation of intracellular Ca with BAPTA/AM inhibited the actions of insulin without affecting basal values. Calmodulin (CaM) inhibitors, trifluoperazine and W-7, inhibited the actions of insulin more than $90 \%$. These results indicate that insulin directly increases $\mathrm{NaCl}$ reabsorption in the MTAL, which requires the activation of Ca-CaM system, independent of the adenylate cyclase-cAMPPKA system. In conclusion, insulin directly stimulates $\mathrm{NaCl}$ reabsorption in the in vitro microperfused rabbit PST and MTAL. (Hypertens Res 1996; 19 Suppl. I: S41-S45)
\end{abstract}

Key Words: kidney, in vitro microperfusion, $\mathrm{NaCl}$, proximal tubule, thick ascending limb

Insulin is considered to have a sodium-retaining action in the kidney, thereby involved in the pathophysiology of hypertension $(1,2)$. Apparently insulin has a direct effect on tubular transport, as insulin reduces urinary sodium excretion without altering renal hemodynamics or glomerular filtration rate. Moreover, insulin increases free water clearance, indicating that the hormone increases sodium reabsorption in diluting segments (1). As for insulin receptors, specific binding is greatest in the thick ascending limb, distal convoluted tubules and proximal tubules (3).

Baum reported that insulin stimulates reabsorption of fluid, $\mathrm{Cl}, \mathrm{HCO}_{3}$ and probably also $\mathrm{Na}$ in isolated perfused rabbit proximal convoluted tubules (4). In proximal tubules, $\mathrm{Na}$ reabsorption across the brush border membrane depends on $\mathrm{Na} / \mathrm{H}$ exchange driven by an electrochemical gradient created by $\mathrm{Na} / \mathrm{KATPase}(5)$. Renal acidification in this segment is mediated mainly by $\mathrm{Na} / \mathrm{H}$ exchange in the luminal membrane and $\mathrm{Na}-\mathrm{HCO}_{3}$ cotransporter in the basolateral membrane $(6,7)$. $\mathrm{Na}$ and $\mathrm{HCO}_{3}$ reabsorptions are mainly accomplished by active transport, which involves $\mathrm{Na} / \mathrm{H}$ exchange. However, insulin effect on $\mathrm{Na} / \mathrm{H}$ exchange is controversial. Fine and colleagues demonstrated that insulin increases $\mathrm{Na} / \mathrm{H}$ exchange in primary cultures of rabbit proximal tubular cells (8). In contrast, Mellas and co-workers reported that insulin had no stimulatory effect on $\mathrm{Na} / \mathrm{H}$ exchange in canine proximal tubular cells (9). We here examined whether insulin activates $\mathrm{Na} / \mathrm{H}$ antiport in proximal tubules and stimulates electrolyte transport by monitoring intracellular $\mathrm{pH}(\mathrm{pHi})$ using a fluorescent technique.

Although insulin is suggested to increase $\mathrm{Na}$ reabsorption in diluting segments such as the thick ascending limb of Henle's loop (TAL), previous in vivo reports did not elucidate whether insulin modulates $\mathrm{NaCl}$ absorption by its direct effect on renal tubules or by its effects on local or systemic factors that affected $\mathrm{NaCl}$ transport in renal tubules $(3,10)$. Indeed, Friedberg and associates recently demonstrated in humans that increased $\mathrm{Na}$ reabsorption in the diluting segment during insulin infusion is largely secondary to insulin-induced hypokalemia, because $\mathrm{Na}$ retention by insulin could be prevented by simultaneous $\mathrm{K}$ infusion in an amount sufficient to prevent a fall in plasma $\mathrm{K}$ concentration (11). These results contradict the idea that insulin exerts direct tubular effects. Therefore we examined whether insulin directly affects $\mathrm{NaCl}$ reabsorption in TAL using isolated perfused tubules.

From the Second Department of Internal Medicine, Tohoku University School of Medicine, 1-1 Seiryo-machi, Aoba-ku, Sendai, Japan.

Address for Reprints: N. Takahashi, M.D., Ph.D., the Second Department of Internal Medicine, Tohoku University School of Medicine, 1-1 Seiryo-machi, Aoba-ku, Sendai 980-77, Japan. 


\section{Methods}

\section{In Vitro Microperfusion of Isolated Proximal} Tubules

S2 segments of proximal straight tubules (PST) of female Japanese white rabbits were dissected and perfused on the stage of an inverted microscope (IMT-2: Olympus, Tokyo, Japan) as previously described (12). The perfusion chamber was continuously perfused with isotonic standard saline preheated to $38^{\circ} \mathrm{C}$. The perfusate and the bathing solution were identical and the composition of the solutions was (in mmol/l), $120 \mathrm{NaCl}, 3 \mathrm{KCl}, 1.5 \mathrm{CaCl}_{2}$, $1 \mathrm{MgCl}_{2}, 2 \mathrm{KH}_{2} \mathrm{PO}_{4}, 25 \mathrm{NaHCO}_{3}, 5.5$ glucose and 5 L-alanine gassed with $5 \% \mathrm{CO}_{2}-95 \% \mathrm{O}_{2}$, or 135 $\mathrm{NaCl}, 3 \mathrm{KCl}, 1.5 \mathrm{CaCl}_{2}, 1 \mathrm{MgCl}_{2}, 2 \mathrm{KH}_{2} \mathrm{PO}_{4}, 10$ Hepes, 5.5 glucose and $5 \mathrm{~L}$-alanine, adjusted to $\mathrm{pH}$ 7.4 by $\mathrm{NaOH}$ and gassed with $100 \% \quad \mathrm{O}_{2}$. The tubules were loaded with the acetoxymethyl derivative of a $\mathrm{pH}$ sensitive dye $2^{\prime}, 7^{\prime}$-bis-(2-carboxyethyl)5,(6)-carboxyfluorescein (BCECF/AM) in $10 \mu \mathrm{M}$ from the lumen (12). Fluorescence was measured by a fluorescence microscope equipped with a photomultiplier (OSP-PMU, Olympus) alternately at 490 and $440 \mathrm{~nm}$ excitation, and an emission wave length of $530 \mathrm{~nm}$. The excitation ratio was converted to $\mathrm{pHi}(12)$.

In Vitro Microperfusion of Isolated Medullary Thick Ascending Limbs

The medullary thick ascending limbs (MTAL) of female Japanese white rabbits were microdissected and microperfused in vitro as previously described (13). The perfusate and the bathing solution were identical and the composition of the solutions was (in mmol/l) $120 \mathrm{NaCl}, 3 \mathrm{KCl}, 1.5 \mathrm{CaCl}_{2}, 1 \mathrm{MgCl}_{2}, 2$ $\mathrm{KH}_{2} \mathrm{PO}_{4}, 10$ Hepes, 5.5 glucose, and 5 L-alanine, adjusted to $\mathrm{pH} 7.4$ by $\mathrm{NaOH}$ and gassed with $100 \%$ $\mathrm{O}_{2}$. Then the transepithelial voltage $(\mathrm{Vt})$ and $\mathrm{Cl}$ concentration of the perfusate were measured (13). Because TAL is water impermeable, we can calculate $\mathrm{J}_{\mathrm{Cl}}$ from the decrease in luminal $\mathrm{Cl}$ concentration (13).

The present study was carried out in accordance with the Guide for Animal Experimentation, Toho$\mathrm{ku}$ University and Tohoku University School of Medicine.

\section{Chemicals}

Bovine insulin, dibutyryl-adenosine $3^{\prime}, 5^{\prime}$-cyclic monophosphate (dbcAMP), trifluoperazine, and W7 were purchased from Sigma Chemical (St. Louis, MO, USA). BCECF/AM was from DOJIN Chemical Institute (Kumamoto). H-8 was purchased from Seikagaku (Tokyo). All other chemicals were purchased from Wako Pure Chemical Industries (Osaka).

\section{Statistical Analysis}

The data were analyzed using the paired $t$-test. Results are reported as mean $\pm \mathrm{SE}$. A $p$ value of $<$ 0.05 was accepted for statistical significant. insulin

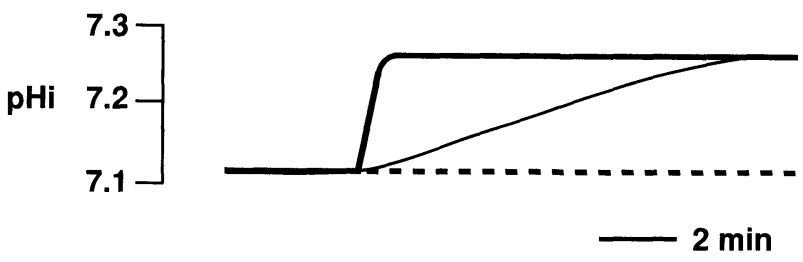

Fig. 1. Effects of insulin on pHi of S2 PST. In a $\mathrm{CO}_{2}$ $\mathrm{HCO}_{3}$-buffered solution, insulin $\left(10^{-6}\right.$ molll) added to the bath gradually increased pHi (thin line). In a Hepes-buffered solution, insulin $\left(10^{-6} \mathrm{~mol} / \mathrm{l}\right)$ added to the bath immediately increased pHi (thick line). In the presence of amiloride $\left(10^{-3} \mathrm{~mol} / \mathrm{l}\right)$ in the lumen, insulin-induced $\mathrm{pHi}$ increase was abolished (broken line).

\section{Results}

Effect of Insulin on pHi in PST

In a $\mathrm{CO}_{2}-\mathrm{HCO}_{3}$ - buffered solution, the addition of insulin $\left(10^{-6} \mathrm{~mol} / \mathrm{l}\right)$ to the bath gradually increased pHi from $7.11 \pm 0.02$ to $7.26 \pm 0.02(n=4, p<0.005)$ at a rate of $0.0272 \pm 0.0069(\mathrm{dpHi} / \mathrm{min})$, and it reached steady-state within $10 \mathrm{~min}$ (Fig. 1). The insulin-induced alkalization of pHi may be the results of various combinations of interactions between stimulating and/or inhibiting acid-base transporters such as $\mathrm{Na} / \mathrm{H}$ exchanger, $\mathrm{Na} / \mathrm{HCO}_{3}$ cotransporter, $\mathrm{Cl} / \mathrm{HCO}_{3}$ antiporter and $\mathrm{H}$ ATPase. In a Hepes-buffered solution, the contribution of transporters involving $\mathrm{HCO}_{3}$ becomes minimal. In a Hepes-buffered solution, insulin $\left(10^{-6} \mathrm{~mol} / \mathrm{l}\right)$ rapidly increased pHi from 7.11 \pm 0.04 to $7.26 \pm 0.04(n=$ $7, p<0.0001)$ at a rate of $0.416 \pm 0.126(\mathrm{dpHi} / \mathrm{min})$, which reached steady state within a minute (Fig. 1). Insulin increased $\mathrm{pHi}$ in a dose-dependent manner and at physiological concentrations. These results strongly suggest that the transporter contributing to insulin-mediated $\mathrm{pHi}$ increase is $\mathrm{Na} / \mathrm{H}$ exchanger. To confirm this hypothesis, we examined the effects of insulin in the presence of $10^{-3} \mathrm{~mol} / \mathrm{l}$ amiloride, an inhibitor of $\mathrm{Na} / \mathrm{H}$ antiport, in the lumen. The increase in pHi by insulin was almost completely inhibited by amiloride (Fig. 1), indicating that the insulin-induced increase in $\mathrm{pHi}$ is largely mediated by the stimulation of luminal $\mathrm{Na} / \mathrm{H}$ exchange.

\section{Effect of Insulin on Electrolyte Transport of MTAL} The addition of insulin $\left(10^{-6} \mathrm{~mol} / \mathrm{l}\right)$ to the bath gradually increased Vt from $3.1 \pm 0.3$ to $5.7 \pm 0.3 \mathrm{mV}$ $(n=12, p<0.0001$, Fig. 2). The effect of insulin was observed in a dose-dependent manner and at physiological concentrations and its $\mathrm{ED}_{50}$ was $5 \times 10^{-9}$ $\mathrm{mol} / \mathrm{l}$. Moreover, insulin $\left(10^{-6} \mathrm{~mol} / \mathrm{l}\right)$ increased $\mathrm{J}_{\mathrm{Cl}}$ from $143 \pm 15$ to $292 \pm 37 \mathrm{pmol} \cdot \mathrm{mm}^{-1} \cdot \mathrm{min}^{-1}(n=5$, $p<0.005)$, indicating that $\mathrm{Vt}$ reflects increase in $\mathrm{NaCl}$ reabsorption.

Several peptide hormones such as vasopressin, calcitonin, glucagon, and $\beta$-adrenergic agonists have been shown to increase $\mathrm{NaCl}$ reabsorption by stimu- 


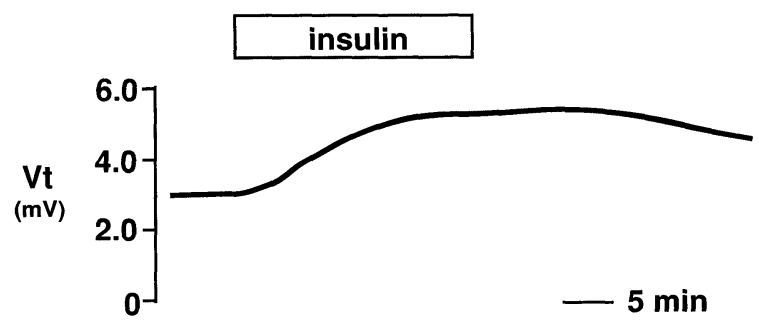

Fig. 2. Effects of insulin on Vt of MTAL. Insulin $\left(10^{-6}\right.$ molll) added to the bath gradually increased Vt, which reached a maximal value within 20 min. Elimination of insulin gradually decreased Vt to the control level.

lating adenylate cyclase in TAL. Therefore we examined whether cAMP also contributes to the effect of insulin in MTAL. Insulin further increased Vt in the presence of dbcAMP (control, $3.3 \pm 0.3 \mathrm{mV}$; dbcAMP in $5 \times 10^{-4} \mathrm{~mol} / \mathrm{l}, 4.8 \pm 0.1 \mathrm{mV}$; dbcAMP + insulin in $10^{-6} \mathrm{~mol} / 1,6.6 \pm 0.4 \mathrm{mV} ; n=4, p<$ $0.005)$. In addition, a selective inhibitor of cAMPdependent protein kinase (PKA), H8 $\left(5 \times 10^{-5}\right.$ mol/1), did not inhibit the insulin stimulated increase in $\mathrm{Vt}$, whereas it inhibited the increase in $\mathrm{Vt}$ by dbcAMP, suggesting that the effect of insulin on $\mathrm{NaCl}$ transport in MTAL is not mediated by adenylate cyclase-cAMP-PKA cascade.

As $\mathrm{Ca}$ is suggested to be involved in the signal transduction of insulin in glucose transport in adipocytes, we examined the role of $\mathrm{Ca}$ in insulin-stimulated $\mathrm{Cl}$ transport in MTAL. Removal of extracellular Ca with EGTA did not affect the insulin-stimulated increase in $\mathrm{Vt}$. In addition, when intracellular $\mathrm{Ca}\left(\left[\mathrm{Ca}^{2+}\right]_{\mathrm{i}}\right)$ was measured using fura- 2 , insulin did not change $\left[\mathrm{Ca}^{2+}\right]_{i}$. However, chelation of intracellular $\mathrm{Ca}$ with BAPTA/AM inhibited the actions of insulin without affecting basal values. Furthermore, calmodulin (CaM) inhibitors, trifluoperazine and W-7 inhibited the actions of insulin more than $90 \%$. These results indicate that $\mathrm{Ca}-\mathrm{CaM}$ system is important in the actions of insulin in MTAL.

\section{Discussion}

In the present study we examined the direct effects of insulin on electrolyte transport in the isolated in vitro microperfused PST and MTAL.

\section{Effects of Insulin on pHi of PST}

The results indicate that the insulin-induced pHi increase is largely dependent on the stimulation of luminal $\mathrm{Na} / \mathrm{H}$ exchange, which is the key transporter in $\mathrm{Na}, \mathrm{Cl}$ and $\mathrm{HCO}_{3}$ reabsorption in the proximal tubules. Brush border $\mathrm{Na} / \mathrm{H}$ exchange is regulated by various hormones and pathophysiological states. For example, glucocorticoids (14), thyroid hormones (15) and metabolic acidosis (16) increased $\mathrm{Na} / \mathrm{H}$ exchange in brush border membrane vesicles isolated from rats. Insulin and prostaglandin $E_{1}$ stimulated $\mathrm{Na} / \mathrm{H}$ exchange in cultured proximal tubular cells (8). Gesek and coworkers demon strated that insulin and hormones that stimulate $\mathrm{Na} / \mathrm{H}$ exchange ( $\alpha_{1}$ adrenoceptor agonists, $\alpha_{2}$ adrenoceptor agonists and angiotensin II) had no synergistic effects; in addition, with hormones that inhibit $\mathrm{Na} / \mathrm{H}$ exchange (parathyroid hormone, dopamine), insulin stimulation was decreased (17). In our study, the interaction between insulin and other hormones that modulate $\mathrm{Na} / \mathrm{H}$ exchange was not examined.

The apical membrane as well as the basolateral membranes of the proximal tubules have insulin receptors $(18,19)$. We also tested the effect of insulin in the lumen and obtained the result that $\mathrm{pHi}$ was unchanged (data not shown). Our data are in good agreemet with that by Baum (4). Therefore, insulin binding capacity of brush border membranes may indicate the presence of its clearance receptor and that luminal insulin plays no significant role on water and electrolyte transport of proximal tubules (20).

It has been shown that insulin stimulates $\mathrm{Na} / \mathrm{K}$ ATPase in the basolateral membrane of the rabbit renal cortex (21) and dog kidney (22). Feraille et al. have demonstrated that insulin increases the initial rate of ouabain-sensitive ${ }^{86} \mathrm{Rb}$ uptake in rat proximal convoluted tubule (23). Therefore insulin-induced stimulation of $\mathrm{Na} / \mathrm{H}$ exchange may be the result of $\mathrm{Na} / \mathrm{K}$-ATPase activation. However, Hunley and coworkers demonstrated that insulin-induced stimulation of proximal tubule volume reabsorption in rabbits is not associated with changes in cAMP or $\mathrm{Na} / \mathrm{K}$-ATPase activity (24). Gesek and Schoolworth demonstrated in rat proximal tubule suspension that insulin stimulated amiloride-sensitive $\mathrm{Na}$ uptake in the presence of a Na/K-ATPase inhibitor. Therefore an $\mathrm{Na} / \mathrm{K}$-ATPase-independent mechanism can not be ruled out. In contrast to the results of our study, in micropunctured proximal tubules hyperinsulinemia decreased $\mathrm{Na}$ reabsorption (2) or had no effect on proximal tubule fluid or $\mathrm{Cl}$ reabsorption under sustained volume expansion in euglycemic rats (25). This discrepancy may be due to initial insulin level and nephron heterogeneity as well as to differences in species and experimental conditions. The existence of other hormones may also account for the difference.

Effect of Insulin on Electrolyte Transport of MTAL The isolated perfused tubule is a preferred model for examining the direct effects of insulin on renal tubules, because this preparation allows examination without influence of in vivo conditions. In TAL, transepithelial $\mathrm{Cl}$ reabsorption occurs as a secondary active process via an apical $\mathrm{Na}-\mathrm{K}-2 \mathrm{Cl}$ cotransporter. As shown by our data, both furosemide in the lumen and ouabain in the bath abolished the effect of insulin on $\mathrm{Vt}$, indicating that insulin stimulates transcellular $\mathrm{Cl}$ reabsorption. The present data, however, do not provide information about which transporter insulin primarily activates. Feraille and associates demonstrated in rat kidney that insulin inhibited the rate of ouabain-sensitive ${ }^{86} \mathrm{Rb}$ uptake in the TAL by $44 \%$ indicating the inhibitory effect of insulin on $\mathrm{Na} / \mathrm{K}-\mathrm{ATPase}(23)$. It seems unlikely that the inhibition of $\mathrm{Na} / \mathrm{K}$-ATPase results in 
the stimulation of transcellular $\mathrm{NaCl}$ reabsorption. At present, we do not know whether this is also the case in rabbit MTAL.

A PKA inhibitor did not inhibit the actions of insulin on $\mathrm{Vt}$ or $\mathrm{J}_{\mathrm{Cl}}$, but did inhibit the effect of dbcAMP, indicating that the effect of insulin is independent of adenylate-cyclase cAMP-PKA system. In agreement with the present results, Morel reported that insulin did not affect adenylate cyclase activity in the rabbit nephron (26). It has been demonstrated that various short-term effects of insulin are mediated either by protein phosphorylation brought about by activation of the intrinsic tyrosine kinase activity of the insulin receptors or by intracellular production of phosphatidylinositol glycan and diacylglycerol from membrane glycophospholipids (27-29). In our preliminary study, genistein, a tyrosine kinase inhibitor, inhibited the effects of insulin in MTAL.

We have demonstrated that neither extracellular $\mathrm{Ca}$ removal nor verapamil affects the actions of insulin in MTAL (30), suggesting that extracellular $\mathrm{Ca}$ or $\mathrm{Ca}$ influx is not necessary for the actions of insulin. The antagonizing effects of the $\mathrm{Ca}$ channel blocker on insulin antinatriuresis may be mediated by changes in renal medullary hemodynamics. The renal medullary hemodynamics may be important for insulin antinatriuresis in addition to the direct tubular effect of insulin. Although extracellular $\mathrm{Ca}$ or $\mathrm{Ca}$ influx is not necessary for insulin-stimulated $\mathrm{NaCl}$ transport in MTAL, it is possible that the actions of insulin are due to the involvement of intracellular Ca. Direct measurements of $\left[\mathrm{Ca}^{2+}\right]_{\mathrm{i}}$ with fura-2 showed that insulin did not change $\left[\mathrm{Ca}^{2+}\right]_{\mathrm{i}}$ in MTAL cells, but chelation of intracellular $\mathrm{Ca}$ by BAPTA/AM inhibited insulin-stimulated $\mathrm{Vt}$, indicating that intracellular $\mathrm{Ca}$ is required for the actions of insulin in MTAL. Furthermore, two chemically dissimilar $\mathrm{CaM}$ inhibitors inhibited the actions of insulin. Previous reports have provided evidence of interaction between insulin receptor and $\mathrm{CaM}$. Insulin directly stimulates $\mathrm{CaM}$ binding to plasma membranes (31). The insulin receptor contains a CaM-binding domain (32). CaM enhances insulinstimulated phosphorylation of the $\beta$ subunit of the insulin receptor, and insulin also stimulates phosphorylation of CaM (33). Our results suggest that $\mathrm{CaM}$ mediates insulin receptor or post-receptor signal transduction.

In summary, insulin stimulates $\mathrm{Na}$ reabsorption by activating luminal $\mathrm{Na} / \mathrm{H}$ exchange in rabbit $\mathrm{S} 2$ PST. Insulin directly increases $\mathrm{NaCl}$ reabsorption in MTAL, which requires the activation of intracellular $\mathrm{Ca}-\mathrm{CaM}$ system, independent of the adenylate cyclase-cAMP-PKA system.

\section{References}

1. DeFronzo RA, Cooke C, Andres R, Faloona G, Davis P: The Effect of Insulin on Renal Handling of Sodium, Potassium, Calcium, and Phosphate in Man. $J$ Clin Invest 1975; 55: 845-855.

2. DeFronzo R, Goldberg M, Agus Z: The Effects of Glucose and Insulin on Renal Electrolyte Transport.
J Clin Invest 1976; 58: 83-90.

3. Butlen D, Vadrot S, Roseau S, Model F: Insulin receptors along the rat nephron: [125I] insulin binding in microdissected glomeruli and tubules. Pflugers Arch 1988; 412: 604-612.

4. Baum M, Berry C: Evidence for neutral transcellular transport and neutral basolateral chloride exit in rabbit proximal convoluted tubule. J Clin Invest 1984; 74: 205-211.

5. Preising P, Rector F: Role of $\mathrm{Na}-\mathrm{H}$ antiport in rat proximal tubule $\mathrm{NaCl}$ absorption. Am J Physiol 1988; 255 (Renal Fluid Electrolyte Physiol. 24): F461-F465.

6. Kondo Y, Frömter E: Axial heterogeneity of sodiumbicarbonate contransport in proximal straight tubule of rabbit kidney. Pflugers Arch 1987; 410: 481-486.

7. Yoshitomi K, Burckhardt B, Frömter E: Rheogenic sodium-bicarbonate cotransport in the peritubular cell membrane of rat renal proximal tubule. Pflugers Arch 1985; 405: 360-366.

8. Fine L, Badie-Dezfooly B, Lowe A, Hamzeh A, Wells J, Salehmoghaddam S: Stimulation of $\mathrm{Na} / \mathrm{H}$ antiport is an early event in hypertrophy of renal proximal tubular cells. Proc Natl Acad Sci USA 1985; 82: $1736-1740$.

9. Mellas J, Gavin J, Hammerman M: Multiplicationstaining activity-induced alkalinization of canine renal proximal tubular cells. J Biol Chem 1986; 261: 14437-14442.

10. Nakamura R, Emmanouel DS, Katz AI: Insulin binding sites in various segments of the rabbit nephron. J Clin Invest 1983; 72: 388-392.

11. Friedberg CE, Buren MV, Bijisma JA, Koomans HA: Insulin increases sodium reabsorption in diluting segment in humans: Evidence for indirect mediation through hypokalemia. Kidney Int 1991; 40: 251-256.

12. Takahashi N, Kondo $\mathbf{Y}$, Ito O, Igarashi Y, Yoshinaga $\mathrm{K}$, Abe $\mathrm{K}$ : Insulin stimulates luminal $\mathrm{Na}-\mathrm{H}$ antiport in rabbit S2 proximal straight tubules. Nutr Metab Cardiovasc Dis 1993; 3: 73-77.

13. Ito $\mathrm{O}$, Kondo $\mathrm{Y}$, Takahashi $\mathrm{N}$, et al: Insulin stimulates $\mathrm{NaCl}$ transport in isolated perfused MTAL of Henle's loop of rabbit kidney. Am J Physiol 1994; 267 (Renal Fluid Electrolyte Physiol. 36): F265-F270.

14. Freiberg J, Kinsella J, Sacktor B: Glucocorticoids increase the $\mathrm{Na}-\mathrm{H}$ exchange and decrease the $\mathrm{Na}$ gradient-dependent phosphate-uptake systems in renal brush border membrane vesicles. Proc Natl Acad Sci 1982; 79: 4932-4936.

15. Kinsella J, Sacktor B: Thyroid hormones increase $\mathrm{Na} / \mathrm{H}$ exchange activity in renal brush border membranes. Proc Natl Acad Sci USA 1985; 82: 3606-3610.

16. Cohn D, Klahr S, Hammerman M: Metabolic acidosis and parathyroidectomy increase $\mathrm{Na}-\mathrm{H}$ exchange in brush border vesicles. Am J Physiol 1983; 245 (Renal Fluid Electrolyte Physiol. 11): F217-F222.

17. Gesek F, Schoolwerth A: Insulin increases $\mathrm{Na}^{+}-\mathrm{H}^{+}$ exchange activity in proximal tubules from normotensive and hypertensive rats. Am J Physiol 1991; 260 (Renal Fluid Electrolyte Physiol. 29): F695-F703.

18. Talor Z, Emmanouel D, Katz A: Insulin binding and degradation by luminal and basolateral tubular membranes from rabbit kidney. J Clin Invest 1983; 69: 1136-1146.

19. Rabkin R, Ryan M, Duckworth W: The renal metabolism of insulin. Diabetologia 1984; 27: 351-357.

20. Hellfritzsch M, Christensen E, Sonne O: Luminal uptake and intracellular transport of insulin in renal proximal tubules. Kidney Int 1986; 29: 983-988.

21. Taylor Z, Emmanouel D, Katz A: Insulin stimulates Na-K-ATPase activity of basolateral renal tubular membranes. Kidney Int 1982; 21 (Suppl 1): 266(Ab- 
stract).

22. Rivera C, Reyes-Santos H, Martinez-Maldonado M: Response of dog renal Na-K ATPase to insulin in vitro. Renal Physiol 1978; 1: 74-83.

23. Feraille E, Marsy S, Cheval L, et al: Sites of antinatriuretic action of insulin along rat nephron. $A m J$ Physiol 1992; 263 (Renal Fluid Electrolyte Physiol. 32): F175-F179.

24. Hunley T, Baum M, Marver D: Na/K ATPase activity in the rabbit proximal convoluted tubule (PCT) in response to insulin. Kidney Int 1987; 31: 436.

25. Kirchner K: Insulin increases loop segment chloride reabsorption in the euglycemic rat. Am $J$ Physiol 1988; 255 (Renal Fluid Electrolyte Physiol. 24): F1206-1213.

26. Morel F: Sites of hormone action in the mammalian nephron. Am J Physiol 1981; 240 (Renal Fluid Electrolyte Physiol. 9): F159-F164.

27. Cherqui G, Reynet $\mathrm{C}$, Caron $\mathrm{M}$, et al: Insulin receptor tyrosine residues 1162 and 1163 control insulin stimulation of myristoyl-diacylglycerol generation and subsequent activation of glucose transport. J Biol
Chem 1990; 265: 21254-21261.

28. Saltiel AR, Cuatrecasas P: In search for a second messenger for insulin. Am J Physiol 1998; 255 (Cell Physiol. 24): C1-C11.

29. Stralfors P: Insulin stimulation of glucose uptake can be mediated by diacylglycerol in adipocytes. Nature 1988; 335: 554-556.

30. Ito $\mathrm{O}$, Kondo $\mathrm{Y}$, Takahashi $\mathrm{N}$, Omata $\mathrm{K}$, Imai $\mathrm{Y}$, Abe K: Verapamil does not directly prevent insulinstimulatory action on $\mathrm{NaCl}$ transport in the medullary thick ascending limb of Henle. J Hypertens 1994; 12 (Suppl.) 3: S102.

31. Goewert RR, Klavan NB, McDonald JM: Direct effect of insulin on the binding of calmodulin to rat adipocyte plasma membranes. J Biol Chem 1983; 258: $9995-9999$.

32. Graves CB, Goewert RR, McDonald JM: The insulin receptor contains a calmodulin-binding domain. Science 1985; 230: 827-829.

33. Graves CB, Gale RD, Laurino JP, McDonald JM: The insulin receptor and calmodulin. J Biol Chem 1986; 261: 10429-10438. 